\title{
UU Antimonopoli Indonesia: . Suatu Telaah Orientasi dan Implikasinya terhadap Perilaku Pelaku Bisnis dan Konsumen
}

\author{
Muryati Marzuki
}

\begin{abstract}
To minimalize the effect of this code from unfaimess conduct of bussinessmen, KPPU and court should control its application. However, the making of this code has contributed positively the economical aspect of national development.
\end{abstract}

\section{Pendahuluan}

Era globalisasi akan ditandai dengan maraknya persaingan antar perusahaan, baik pada tingkat lokal, nasional maupun internasional. Hal ini dapat dimengerti oleh karena mereka sama-sama menginginkan agar akses perusahaannya terhadap pasar dapat diperluas.

Kini bangsa Indonesia memiliki UU No. 5 Tahun 1999 tentang Larangan Praktik Monopoli dan Persaingan Usaha Tidak Sehat. ${ }^{1}$ Keberadaan UU Larangan Praktik Monopoli dan Persaingan Usaha Tidak Sehat memang belum lama, tetapi kalau mencermati kepada substansi UU ini ada beberapa hal yang menarik untuk ditelaah. Hal itu berkaitan dengan masalah orientasi dari UU Larangan Praktik Monopoli dan akibat yang ditimbulkan dari orientasi tersebut.

Orientasi dari UU Larangan Praktik Monopoli dan Persaingan Usaha Tidak Sehat adalah melindungi kepada kepentingankepentingan usaha kecil, koperasi dan Badan Usaha Milik Negara, serta kepentingankepentingan pengusaha yang lebih kuat.

'Selanjutnya UU No. 5 Tahun 1999 tentang Larangan Praktik monopoli dan Persaingan Usaha Tidak Sehat dalam tulisan ini disebut UU Larangan Praktik Monopoli dan Persaingan Usaha Tidak Sehat. 
Implikasi dari orientasi ini sangat jelas akan membawa dampak pada prilaku persaingan pelaku bisnis yang cenderung akan kurang "mempedulikan", mengingat perlakuan dari aturan ini yang diskriminatif. Akibat berikutnya dengan orientasi yang ada sekarang di dalam UU Larangan Praktik Monopoli dan Persaingan Usaha Tidak Sehat konsumen juga akan sangat dirugikan.

\section{Sekilas Pemikiran Dibentuknya UU Antimonopoli di Indonesia}

Dijumpainya monopoli dan oligopoli, monopsoni, posisi dominan dan berbagai bentuk persaingan tidak sehat lainnya dalam dunia perdagangan merupakan suatu bentuk nyata atas terjadinya defiasi-defiasi pasar. Dengan terjadinya defiasi-defiasi itu, pasar menjadi sebuah media yang tidak sehat, pasar menjadi disfungsional bagi tujuan pensejahteraan rakyat. $^{2}$

Fakta ini memaksa harus mengakui bahwa model bisnis yang kapitalistik, sangat tidak resisten terhadap berbagai defiasi yang menyebabkan disfungsionalisasi pasar bagf pensejahteraan rakyat. Sekaligus ini memaksa semua untuk merenung dan mereevaluasi pengakuan yang selama ini dipegang bahwa capitalism is the only way to achieve welfare society. ${ }^{3}$
Kalau diperbandingan dengan model perekonomian Islam hal seperti ini sangat jauh sekali dari apa yang seharusnya. Dalam perekonomian Islam yang terpenting ialah keinginan untuk mencapai keuntungan sosial yang sebanyak-banyaknya. Karena itu tiap kegiatan ekonomi yang mungkin merintangi tercapainya tujuan ini tidak dapat dinyatakan bersifat Islami. Dinilai dari norma kebajikan dan pemeliharaan untuk golongan miskin tidak mungkin mengajurkan usaha monopoli dan spekulatif dalam Islam. ${ }^{4}$

Abdul Manan menegaskan walaupun banyak keuntungan teoritik sistem usaha bebas yang tergantung pada asumsi tersirat yaitu terdapatnya persaingan bebas, tetapi celakanya kegiatan kapitalisme yang sesungguhnya telah menambah kekuasaan dan pengaruh perserikatan, kartel, dan monopoli-monopoli raksasa. Para konsumen, pekerja miskin, dan masyarakat secara keseluruhan pun menjadi korban dari suatu tatanan ekonomi yang didominasi monopoli seperti itu-suatu tatanan yang telah memperlihatkan tiadanya harmoni antara kepentingan pribadi dan sosial, antara milik pribadi dan sosial. ${ }^{5}$

Melihat kepada maraknya defiași-defiasi pasar yang membawa ekses sangat dasyat bagi tingkat kesejahteraan masyarakat suatu negara, maka beberapa negara mencoba memberi beberapa solusi. Solusi itu antara lain

${ }^{2}$ Agus Triyanta. "Resistensi Sistem Bisnis Islami dan Sistem Bisnis Sekuler terhadap Defiasi Pasar." Jumal Magister Hukum Vol. 2 No. 4. Oktober 2000. HIm. 97.

3/bid.

${ }^{4}$ Abdul Mannan. 1995. Teori dan Praktik Ekonomi Islam. Yogyakarta: PT. Dana Bhakti Wakaf. HIm. 290.

${ }^{5}$ lbid. 
dari segi hukum. Amerika serikat yang selama ini dipandang sebagai negara nenek moyangnya lahir konsep ekonomi kapitalistik, ternyata mereka sudah sangat lama memiliki ketentuan-ketentuan yang terkait dengan masalah praktik monopoli dan persaingan usaha tidak sehat, di samping negara lainnya seperti; Jerman, Philipina. ${ }^{6}$

Bagi Indonesia banyak problematika yang muncul ketika sebelum diberlakukannya UU No. 5 Tahun 1999 tentang Larangan Praktik Monopoli dan Persaingan Usaha Tidak Sehat. Kalaupun Indonesia mempunyai aturan mengenai persaingan curang, tetapi aturan itu sangat general dan cenderung bersifat parsial, sehingga aturan terasa kurang lengkap dan jelas. ${ }^{7}$ Akibat hukum dari kurang lengkapnya pengaturan, maka ini menjadi celah bagi para pelaku usaha untuk menyalahgunakan aturan tersebut dan meraup keuntungan yang sebesar-besarnya, tanpa menghiraukan apakah hal itu dibenarkan menurut normanorma maupun etika bisnis yang ada saat itu, semisal; melakukan praktik monopoli dan persaingan usaha tidak sehat.

$\mathrm{Di}$ lain pihak tindakan-tindakan pemerintah $^{8}$ dan birokrasi pun melanggar secara mentah-mentah segala prinsip yang seharusnya dipegang teguh oleh setiap pemerintahan dan administrasi negara yang demokratis (principle of good and clean governance). Oleh sebab itu, tidak mengherankan sekalipun pemerintah senantiasa menggembar-gemborkan bahwa hukum harus ditegakkan, tetapi selama 32 tahun terakhir ternyata pemerintah justru sangat mengabaikan pemberdayaan dan pembangunan berbagai pranata dan sarana maupun peraturan dan lembaga-lembaga hukum, sehingga praktik-praktik yang curang, tidak etis dan tidak bermoral di segala bidang merajalela dan mengerogoti kehidupan

${ }^{6}$ Amerika Serikat misalnya telah mempunyai The Sheman Antitust Act, 1890, The Clayton Antitrust Act, 1914, Robinson Patman Act. 1936. Celler-Kefauver Act. 1950 dan The Federal Trade Comission Act, 1914. Di Jerman telah, ada undang-undang tentang Unfair Competition sejak tahun 1909. Di Philipina ada satu chapter khusus tentang Frauds in Commerce \& Trade pada Penal Codenya yang direvisi pada tahun 1930, dengan Act Nomor 3815 .

${ }^{7}$ Beberapa perangkat hukum tentang persaingan sehat di Indonesia yang parsial tersebut adalah; Pertama, Pasal 382 bis W.V.S. (KUHP) yang menyebutkan bahwa persaingan tidak jujur merupakan perbuatan pidana, Kedua, Pasal 1365 KUHPerdata (BW) yang mana persaingan tidak jujur dapat dikatakan sebagai perbuatan melawan hukum; Ketiga, Pasal 81 dan 82 UU No. 19 Tahun 1992 yang telah diubah dengan UU No. 14 Tahun 1997 dan telah diubah lagi dengan UU No. 31 Tahun 2001 tentang Merek; Keempat, Pasal 7 UU No. 5 Tahun 1984 tentang Perindustrian; Kelima, Bab VII (Pasal 102 s/d Pasal 109) UU No. 1 Tahun 1995 tentang Perseroan Terbatas.

${ }^{8}$ Dalam pengertian ini pemerintah tidak hanya mencakup kepada lembaga eksekutif, tetapi juga meliputi lembaga legislatif dan yudikatif. Khusus untuk lembaga yudikatif, terutama sekali pada peranan aparat penegak hukum nampak bahwa mereka kurang melakukan peranannya dalam mengantisipasi praktik-praktik monopoli dan usaha persaingan tidak sehat. Hal ini boleh jadi banyak faktor yang mempengaruhi. 
seluruh masyarakat, termasuk kegiatan bisnis dan kehidupan ekonomi. ${ }^{9}$

Kebijakan-kebijakan pemerintah lebih banyak diorientasikan pada semakin terkonsentrasinya industri, sehingga melahirkan praktik monopoli. Nurimansyah Hasibuan mengidentifikasi beberapa penyebab terkonsentrasinya industri yang menciptakan praktik monopoli, yaitu: ${ }^{10}$

1. Kemajuan teknologi. Kemajuan teknologi ini pada satu sisi berguna untuk mengatasi rintangan-rintangan lokal dan peningkatan efesiensi. Di sisi lain dapat melahirkan konsentrasi tinggi, sebab tidak semua pengusaha dapat menguasai kinerja efesiensi itu. Dengan demikian, muncul akumulasi modal dan kekayaan di tangan beberapa orang atau kelompok. Dalam hal ini konsentrasi industri menyebabkan dicapainya kedudukan monopoli melalui persaingan dan efisiensi.

2. Perlindungan yang berlebihan. Konsentrasi industri yang melahirkan monopoli juga muncul karena perlindungan yang berlebihan. Perlindunga ini diberikan oleh pemerintah dalam bentuk sebagai berikut: (a) pasar barang jadi yang diproduksi dalam negeri dilindungi dengan tarif normal atau efektif yang tinggi, sedangkan untuk bahan baku yang belum diproduksi atau masih kurang di dalam negeri tarifnya relatif murah. Kadang-kadang kedua jenis perlindungan ini didapatkan pula oleh suatu perusahaan; (b) perlindungan pasar juga dapat dengan penetapan harga jual oleh pemerintah. Tingkat harga yang ditetapkan oleh pemerintah tidak sematamata melindungi konsumen, tetapi juga melindungi perusahaan-perusahaan yang tidak efisien agar terus dapat hidup; (c) menciptakan captive market yang berarti memberikan kedudukan monopoli bagi suatu perusahaan, baik secara nasional, regional, maupun lokal. Pola captive market ini acapkali diklaim bertujuan untuk memperkuat yang lemah. Misalnya dalam upaya mendorong dan mendukung kegiatan koperasi, hampir seluruh kegiatan KUD (Koperasi Unit Desa) mendapatkan captive market.

3. Menciptakan entry barrier (rintangan masuk). Pemerintah memberikan izin kepada perusahaan tertentu memproduksi jenis barang tertentu. Kemudian bila ada pihak lain yang ingin masuk ke jenis industri tersebut pemerintah akan menolak untuk memberikan izin dengan alasan "kapasitas sudah penuh".

9Sunaryati Hartono. "Pembangunan Hukum Ekonomi Indonesia dalam Rangka Mewujudkan Perilaku Bisnis dan Persaingan Usaha yang Sehat." Makalah disampaikan pada Seminar Membenahi Perilaku Bisnis Melalui Undang-Undang Nomor 5 Tahun 1999 tentang Larangan Praktik Monopoli dan Persaingan Usaha Tidak Sehat. Diselenggarakan oleh Sidharta Pohan Prastowo Associates, Hotel Grand Aquila, Bandung 19 Juni 1999. HIm. 4-5.

${ }^{10} \mathrm{Abdul}$ Hakim G. Nusantara dan Benny K. Harman.1999. Analisis dan Perbandingan Anti Monopoli. Jakarta: Kelompok Gramedia. Him.10-11. 
4. Keringan pajak dan subsidi. Konsentrasi industri terjadi juga karena adanya perlindungan pemerintah berupa keinginan pajak dan subsidi. Keringanan pajak dan subsidi yang diberikan kepada perusahaan memungkinkan perusahaan tersebut memperoleh kesempatan untuk melakukan akumulasi modal dari perolehan laba yang tinggi. Subsidi diberikan tidak hanya kepada pengusaha lemah, tetapi juga kepada pihak yang kuat, karena adanya prioritas program, tetapi juga kepada pihak yang kuat, karena adanya prioritas program pemerintah yang mesti dicapai.

5. Konsentrasi terjadi melalui merger di antara perusahaan-perusahan sejenis. Merger yang berarti perusahaan yang lemah dipaksa (terpaksa) bergabung dengan perusahaan sejenis yang lebih kuat dengan sendirinya mengurangi persaingan.

Kecenderungan di atas tidak hanya diikuti oleh pelaku bisnis, tetapi sudah merambah juga kepada masyarakat Indonesia secara keseluruhan. Pola-pola perilaku hukum masyaakat Indonesia tidak ramah lagi kepada mekanisme pasar. Sudah menjadi rahasia umum ketika masyarakat tidak lagi taat kepada pelbagai aturan yang dibuat, bahkan praktikpraktik yang menyimpang dari wujud persaingan sehat telah dianggap sebagai "hukum kebiasaan" (costumery law). Padahal apa yang selama ini diikuti justru mengarah kepada kehancuran ekonomi secara nasional.

Fenomena ini akhirnya mendorong lembaga legislatif" mempergunakan hak inisiatifnya untuk membentuk Undang-Undang Anti Monopoli. Respon positif pun muncul juga dari pemerintah saat itu, meskipun dalam beberapa hal ada perbedaan-perbedaan konseptual, tetapi secara substansial kebutuhan terhadap Undang-Undang Anti Monopoli tidak ada perbedaan. ${ }^{12}$

Salah satu perdebatan konseptual antara pemerintah saat itu adalah berkaitan dengan penggunaan nama undang-undang untuk monopoli dan persaingan usaha tidak sehat. Bagi lembaga legislatif istilah "Larangan Praktik Monopoli" merupakan hal yang tetap dalam pemberian judul dari undang-undang tersebut. Perlu diketahui, secara teoritis sebenarnya ada praktik monopoli yang dilakukan dengan cara yang fair, sehat, baik

\footnotetext{
"Perlu diingat lembaga legislatif selama 32 tahun tidak menggunakan hak inisiatif, dan untuk pertama kalinya lembaga legislatif menggunakan hak inisiatif ini melalui UU Antimonopoli. Peristiwa ini terjadi ketika pada era reformasi. Kenyataannya pada periode 32 tahun lembaga legislatif hanya memerankan fungsi $4 \mathrm{D}$ (duduk, dengar, dengkur, dan duit). Lihat Abdul Gafur. Hari-hari Terakhir Seorang Presiden. Jakarta: Pustaka Sinar Harapan. HIm. 15.

${ }^{12}$ Sebenarnya perdebatan mengenai kebutuhan Undang-Undang Anti Monopoli sudah sangat lama diperbincangan oleh kalangan akademisi maupun LSM, tetapi saat itu pemerintah kurang tanggap atau barangkali karena struktur kekuasaan saat itu lebih berpihak kepada para konglomerat dan juga kekuasaan punya kepentingan. Dalam arti ada beberapa pelaku usaha yang melakukan praktik monopoli dan usaha persaingan tidak sehat mereka sangat terkait dengan istilah KKN (Korupsi, Kolusi, dan Nepotisme), maka upaya-upaya kearah itu tidak pernah dilakukan sama sekali. Kalaupun itu dilakukan pemerintah, maka ancaman terhadap kekuasaan benar-benar akan terjadi.
} 
dan ini disebut dengan monopoli alamiah dan ini perlu didorong, dan ada juga monopoli yang dilakukan dengan cara tidak fair, dan tidak sehat yang sering disebut monopoli artifisial. Bentuk monopoli terakhir inilah sebenarnya yang harus dilarang. Untuk itu pemakaian nama "Larangan Praktik Monopoli" yang diusulkan oleh lembaga legislatif akan sangat menyesatkan. Walaupun harus dapat dimengeti juga bahwa lembaga legislatif menekankan pada peristilahan tersebut semata-mata ingin mengakomodir kehendak kelompok reformis yang menghendaki adanya UU Antimonopoli.

Lain lagi dengan pemerintah yang mengusulkan agar nama/judul undang. undang yang akan dibentuk disebut UndangUndang larangan Persaingan Usaha Tidak Sehat. Usulan ini nampak sangat masuk akal, mengingat UU yang akan dibentuk pada dasarnya akan mengatur larangan terhadap persaingan usaha tidak sehat. Setelah mengalami perdebatan yang sangat a lot antara legislatif (baca: DPR) dengan Pemerintah, maka dicapailah kompromi bahwa undang-undang itu diberi judul dengan sebutan Undang-Undang Larangan Praktik Monopoli dan Persaingan Usaha Tidak Sehat. ${ }^{13}$
Akhirnya pada tanggal 5 Maret 1999 UU ini telah diundangkan menjadi UU No. 5 Tahun 1999 tentang Larangan Praktik monopoli dan Persaingan Usaha Tidak Sehat. Hal ini sekaligus juga membuktikan bahwa era persaingan sehat akan dimulai di Indonesia.

\section{Pengertian dan Bentuk Antimonopoli di Indonesia}

Setelah menelusuri bagaimana kerangka pemikiran munculnya UU Larangan: Praktik Monopoli dan Persaingan Usaha Tidak Sehat, maka yang patut untuk dipahami șekarang berkaitan dengan pengertian monopoli dan persaingan usaha tidak sehat itu sendiri berikut pengaturan hukum yang ada dalam UU tersebut. Untuk mengetahui pengertian dari kedua peristilahan ini, di. sini akan dikemukakan tentang definisi keduanya.

Kata "monopoli" berasal'dari kata Yunani yang berarti "penjual tunggal". Di samping istilah monopoli, di USA sering digunakan kata antitrust untuk pengertian yang sepadan dengan istilah "dominasi" yang dipakai oleh masyarakat Eropa yang artinya juga sepadan dengan arti istilah monopoli. Istilah lainnya' yang mirip-mirip, yaitu istilah "kekuatan pasar". Dalam praktik keempat istilah tersebut, yaitu.

${ }^{13}$ Menurut Abdul Hakim G Nusantara dan Benny K Harman langkah kompromi ini sebenarnya terlalu dipaksakan dan menunjukan ketidak mengertian para pembuat UU terhadap arah dan tujuan yang hendak dicapai melalui UU ini apakah untuk mencegah praktik-praktik bisnis yang curang (anti persaingan) ataukah untuk melarang terjadinya monopoli. Kalau tujuannya adalah untuk melarang terjadinya monopoli. Kalau tujuannya adalah untuk melarang praktik-praktik persaingan yang tidak sehat (praktik bisnis curang), maka nama yang lebih tepat adalah UU Persaingan Sehat. Tetapikalau tujuannya adalah untuk menjegal terjadi 'monopoli', maka memang akan lebih tepat kalau ini dinamakan UU Antimonopoli. Lihat Abdul Hakim G. Nusantara dan Benny K Herman. Op.Cit. HIm. 203. 
istilah "monopoli", antitrust, "kekuatan pasar", dan istilah "dominasi" saling dipertukarkan pemakaiannya. Keempat istilah itu tersebut dipergunakan untuk menunjukkan suatu keadaan di mana seseorang menguasai pasar, di mana di pasar tersebut tidak tersedia lagi produk substitusi atau produk substitusi yang potensial, dan terdapatnya kemampuan pelaku pasar tersebut untuk menerapkan harga produk tersebut yang lebih tinggi, tanpa mengikuti hukum persaingan pasar atau hukum tentang permintaan dan penawaran pasar. ${ }^{14}$

Pengertian lain diberikan juga dalam Black's Law Dictionary. Kamus ini menyatakan bahwa monopoli adalah:15

"a privilege or particular advantage vested in one or more persons or companies consisting in the exclusive right (or power) to carry on a particular business or trade, manufacture a particular article, or control the sale of the whole supply of a particular commodity."

Berdasarkan pada definisi ini, maka jelas bahwa monopoli pada hakekatnya merupakan keuntungan dari perlakuan khusus atau istimewa kepada orang-perorangan atau perusahaa sebagai akibat dari adanya hak istimewa untuk melakukan kegiatan bisnis, baik manufaktur sampai perdagangan, atau dari penjualan sampai suplai dari komoditi khusus tersebut.

Black's Law Dictionary juga mengatakan:16 "Monopoly as prohibited by Section 2 of the Sherman Antitrust Act, has two elements:

1. Possesion of monopoly power in relevan market;

2. Wilful acquisition or maintenance of that power."

Dalam hal ini jelas bahwa monopoli yang dilarang oleh Section 2 dari Sherman Act adalah monopoli yang bertujuan untuk menghilangkan kemampuan untuk melakukan persaingan, dan atau untuk tetap mempertahankannya. ${ }^{17}$

Untuk pengertian persaingan usaha tidak sehat, diambil dari kata competition yang diartikan sebagai:

"Contest of two rivals. The effort of two or more parties, acting independently, to secure the business of a third party by the effort of the most favourable terms; also the relations between different buyers or different sellers which result from this effort (Ingram Corp. v. Circle, Inc. LA.App. 188. So $\left.2^{\text {nd }} 96,98\right)$. It is the Struggle between rivals for the same trade at the same time; the act of seeking or endeavouring to gain at the same time. The term implies

${ }^{14}$ Munir Fuady. 1999. Hukum Anti Monopoli Menyongsong Era Persaingan Sehat. Bandung: PT. Citra Aditya Bakti. HIm. 4.

${ }^{15}$ Bryan A. Ganner. 1999. Black's Law Dictionary. St. Paul Minn: West Group. HIm. 157.

${ }^{16 / b i d .}$

${ }^{17}$ Ahmad Yani dan GunawanWidjaja.1999. Anti Monopoli. Jakarta: PT Raja Grafindo Persada. HIm.13. 
the idea of endeavouring by two or more to obtain the same object or result."

Sementara pengertian dari persaingan usaha tidak sehat sendiri dapat dilihat dalam pengertian unfair competition. Dalam pengertian inj unfair competition adalah:

"All dishonest of fraudulent rivalry in trade or commerce but is particularly applied to the practice of endeavouring to substitute one's own goods or products in the markets for those of another, having an established reputation and extensive sale, by means of immintating or counterfeiting the name, title, size, shape or distinctive particularities of the article, or the shape, color lable, wrapper, or general appearance of package, or other simulation, the immitation being carried for enough to mislead the general public or deceive an unwary purchaiser, and yet not amounting to an absolute counterfeit, or to the infringement of a trademark or trade name. (garis bawah dari penulis)

Ada beberapa persamaan dalam mendefinisikan pengertian unfair competition dengan pengertian persaingan usaha tidak sehat, seperti yang dituangkan dalam Pasal 1 butir 6 UU Larangan Praktik Monopoli dan Persaingan Usaha Tidak Sehat. Pasal tersebut menyatakan:

Persaingan usaha tidak sehat adalah persaingan antar pelaku usaha dalam menjalankan kegiatan produksi dan atau pemasaran barang atau jasa yang dilakukan dengan cara tidak jujur atau melawan hukum atau menghambat persaingan usaha. (garis bawah dari penulis).
Berdasarkan pada penjelasan di atas ini, maka dapat diketahui bahwa letak persamaan pengertian antara unfair competition dan persaingan usaha tidak sehat pada pola tindakan yang dilakukan oleh pelaku bisnis. yaitu pada tindakan yang tidak jujur dalam bidang perdagangan, di mana dampak dari tindakan tersebut akhirnya akan bermuara pada kerugian terhadap kepentingan umum.

Dari kerangka ini tentunya dapat dilihat juga pada bentuk Larangan Praktik monopoli dan Persaingan Usaha Tidak Sehat yang dimaksudkan. Secara substansial UU Larangan Praktik monopoli dan Persaingan Usaha Tidak Sehat di Indonesia mempunyai beberapa bentuk yang dapat dikatakan sebagai praktik monopoli dan persaingan usaha tidak sehat. Ada tiga bentuk utama pengaturan tentang hal itu; Pertama perjanjian yang dilarang. Kedua, bentuk kegiatan yang dilarang; Ketiga, bentuk posisi dominan.

Perjanjian yang dilarang ini kemudian dirinci lagi ke dalam beberapa bentuk di antaranya; 1) oligopoli; 2) penetapan harga; 3) pembagian wilayah; 4) pemboikotan; 5) kartel; 6) trust; 7) oligopsoni; 8) integrasi veritkal; 9) perjanjian tertutup; 10) perjanjian dengan pihak luar negeri, sedangkan yang dikatakan kegiatan yang dilarang, seperti; 1) monopoli; 2) monopsoni; 9) penguasaan pasar; 3) persekongkolan. Dalam hal posisi dominan UU Larangan Praktik Monopoli dan Persaingan Usaha Tidak Sehat di Indonesia menyebutkan, yakni berkaitan dengan jabatan rangkap, pemilik saham, dan penggabungan, peleburan, dan pengambilalihan.

Kalau membandingkan bentuk-bentuk dari perbuatan larangan praktik mononopoli dan persaingan usaha tidak sehat di Indonesia, nampak terlihat adanya pengadopsian bentuk- 
bentuk itu dari bentuk antimonopoli yang ada di negara lain. Misalnya bentuk persekongkolan yang merupakan bagian dari perjanjian yang di larang. Hal ini sama dengan apa yang dilarang di dalam Sherman Act (1890). Section 1 undang-undang ini menyatakan sebagai ilegal setiap kontrak, kobinasi atau persekongkolan yang menghalang-halangi akses pasar dan dengan demikian membatasi persaingan. Section 2 menyatakan juga bahwa perbuatan jahat berlaku bagi barangsiapa yang akan memonopoli, mencoba memonopoli, atau bersekongkol untuk memonopoli bagian apapun dari perdagangan. $^{18}$

Persamaan itu juga terlihat terhadap bentuk penggabungan, peleburan, dan pengambilalihan. Di Jepang, misalnya dalam UU Antimonopoli mengatakan bahwa bilamana persaingan dalam bidang tertentu menjadi terbatas karena adanya akuisisi saham oleh sebuah perusahaan asing atau domestik atas perusahaan domestik lainnya, maka akuisisi atau penguasaan saham (holding of shares) yang demikian itu dilarang.

Dengan bukti-bukti ini, maka dapat disimpulkan bahwa UU Larangan Praktik Monopoli dan Persaingan Usaha Tidak Sehat sangat dipengaruhi oleh pengaturanpengaturan seperti di negara lain yang sudah memiliki undang-undang seperti ini lebih dahulu. Pengaruh ini dapat terjadi secara langsung maupun tidak langsung. Secara langsung melalui studi-studi komparatif, dan secara tidak langsung dapat disebabkan setting dari kerangka pemikiran para pembuat undang-undang itu sendiri.

Orientasi dan Implikasi UU Antimonopoli di Indonesia terhadap Perilaku Pelaku Bisnis dan Konsumen

Orientasi umum dari dihadirkannya suatu UU Persaingan adalah untuk menumbuhkan dan mendorong serta melindungi persaingan sehat dan adil (the maintenance of the competitive process or of free competition or the protection of promotion of effective competition) di dalam pasar. ${ }^{19}$

Iklim persaingan yang sehat memang merupakan suatu conditio sine qua non bagi terselenggaranya ekonomi pasar. Oleh karena itu, undang-undang persaingan merupakan suatu kebutuhan yang mendesak. Bahkan boleh dikatakkan undang-undang persaingan menduduki posisi kunci di dalam ekonomi pasar karena undang-undang tersebut memberikan aturan main yang jelas kepada para pelaku ekonomi. Dengan aturan yang jelas, para pelaku ekonomi mempunyai landasan dalam melaksanakan aktivitasnya. ${ }^{20}$

Untuk Indonesia sekarang boleh berbangga dengan dikeluarkannya UU Larangan Praktik Monopoli dan Persaingan Usaha Tidak Sehat, tetapi kebanggan itu akan terasa hambar apabila menelaah pada misi dan orientasi dari

${ }^{18}$ R.B. Suhartono. "Konglomersai dan Relevansi UU Antitrust/UU Antimonopoli di Indonesia. " Jurnal Hukum Bisnis Vol. 4, 1998. HIm.8.

${ }^{i 9}$ Abdul Hakim G. Nusantara dan Benny K. Herman.Op.Cit. HIm. 204

${ }^{20}$ Normin S. Pakpahan. Op.Cit. HIm 19. 
undang-undang ini. Kehambaran itu didasarkan pada kenyataannya pengaturan hukum yang ada cenderung bukan mengimplementasikan tujuan luhur dari UU Larangan Praktik Monopoli dan Persaingan Usaha Tidak Sehat, terutama dengan adanya kontradiksi dari tujuan dan pengecualian terhadap larangan praktik monopoli dan persaingan usaha tidak sehat.

Dalam UU Larangan Praktik Monopoli dan Persaingan Usaha Tidak Sehat dinyatakan bahwa tujuan undang-undang ini adalah:

1. Menjaga kepentingan umum dan meningkatkan efesiensi ekonomi nasional sebagai salah satu upaya untuk meningkatkan kesejahteraan rakyat;

2. Mewujudkan iklim usaha yang kondusif melalui pengaturan persaingan usaha yang sehat sehingga menjamin adanya kepastian kesempatan berusaha yang sama bagi pelaku usaha besar, pelaku usaha menengah, dan pelaku usaha kecil; (garis bawah dari penulis)

3. Mencegah praktik monopoli dan atau persaingan usaha tidak sehat yang ditimbulkan oleh pelaku usaha, dan;

4. Terciptanya efektivitas dan efesiensi dalam kegiatan usaha.

Dari empat tujuan utama ini yang sangat menarik berada pada point 2 dengan cara membandingkannya dengan pengaturan pengecualian terhadap ketentuan ini. Dalam Pasal 50 UU Larangan Praktik Monopoli dan Persaingan Usaha Tidak Sehat menyatakan bahwa hal-hal yang diperkecualikan dari ketentuan ini meliputi pelaku usaha yang tergolong dalam usaha kecil; dan kegiatan usaha koperasi yang secara khusus bertujuan untuk anggotanya.
Satu kenyataan bahwa bangsa Indonesia dalam pembangunan ekonominya selama ini senantiasa bersandar pada perusahaanperusahaan konglomerasi. Tetapi, bukan berarti pula bahwa tidak ada upaya-upaya untuk memberdayakan ekonomi kecil Pemberdayaan itu telah banyak dilakukan oleh pemerintah, namun pemerintah kurang memahami dari esensi pemberdayaan usaha kecil dan koperasi tersebut.

Metode-metode pemberdayaan yang dilakukan lebih banyak mengakibatkan ketergantungan usaha kecil dan koperasi terhadap pemerintah ketimbang membuat usaha kecil dan koperasi itu bersifat mandiri, dan kebijakan ini kalau ditelaah ulang hampir persis dengan apa yang dilakukan pemerintah terhadap kekuatan konglomerasi di Indonesia.

Hal serupa terulang lagi ketika memformulasikan ketentuan UU Larangan Praktik Monopoli dan Persaingan Usaha Tidak Sehat yang lebih cenderung memanjakan pelaku bisnis, khususnya usaha kecil dan koperasi. Oleh karena itu, melihat kepada masalah ini jelas bahwa tujuan dari UU Larangan Praktik Monopoli bukan bertujuan kepada kepentingan masyarakat dan kepentingan konsumen.

Padahal di beberapa negara pengaturanpengaturan hukum diorientasikan pada perlindungan kepentingan masyarakat dan konsumen, seperti halnya Amerika Serikat. Menurut Deborah Owen, pejabat Komisi Perdagangan Federal Amerika Serikat, tujuan undang-undang Antitrust adalah kesejahteraan konsumen. Dalam rangka menciptakan kesejahteraan konsumen tersebut, Undang-Undang Antitrust Amerika Serikat mencegah atau mematahkan aktivitasaktivitas yang bersifat anti persaingan, para 
pengusaha dapat mengurangi output yang sekaligus menaikan harga jual. Apabila hal ini terjadi sudah barang tentu yang dirugikan adalah konsumen. Di samping itu, undangundang ini juga bertujuan untuk meningkatkan alokasi sumber-sumber daya secara lebih efesien dalam alokasi sumber-sumber tersebut, baik produsen maupun konsumen mempunyai tingkat pemilihan secara optimal. ${ }^{21}$

Dengan adanya perbedaan orientasi ini, maka tidak menuntup kemungkinan akan berimplikasi pada perilaku antar pelaku bisnis dan konsumen. Perilaku yang dimaksudkan bagi para pelaku. bisnis mereka akan cenderung mengabaikan aturan-aturan ini mengingat aturan ini tidak mempunyai misi penciptaan persaingan usaha yang sehat, tetapi justru sangat bertolak belakang dengan hakekat dari keberadaan undang-undang itu sendiri. Di lain pihak, konsumen pun akan banyak dirugikan juga. Akibat tindakantindakan yang dilakukan oleh para pelaku bisnis. Sudah banyak kasus-kasus yang muncul, contohnya kasus antara perusahan Indomart dengan beberapa pengusaha kecil. Dalam kasus ini KPPU telah memberikan tindakan untuk melarang perusahaan Indomart melakukan ekspansi ke wilayahwilayah perusahaan kecil.

Dalam kasus ini dapat saja konsumen belum merasa dirugikan, tetapi apabila intensitas kasus-kasus serupa bermunculan, maka konsumen akan merasakan dengan jelas dampak dari model persaingan semacam itu. Oleh karena itu, agar ini tidak menjadi perilaku yang menyimpang bagi pelaku bisnis, maka peran KPPU dan Pengadilan sangat menentukan dalam melakukan interpretasi terhadap aturan-aturan larangan praktik monopoli dan persaingan usaha tidak sehat.

\section{Simpulan}

Kehadiran UU Larangan Praktik Monopoli dan Persaingan Usaha Tidak Sehat merupakan hal yang positif dalam upaya menciptakan sistem persaingan yang. sehat, fair dan efesien. Supaya maksud positif dapat diwujudkan, maka orientasi dari ketentuan itu pun harus benar-benar dalam kerangka persaingan yang sehat. Dalam beberapa hal UU Larangan Praktik Monopoli sudah cukup bagus, tetapi untuk tujuan dan pengecualian disini UU ini belum sesuai dengan hakekat dari aturan persaingan yang lazim. Orientasi pada perlindungan usaha kecil dan koperasi akan menjadikan kabur hakekat undangundang ini, maka untuk meluruskan tujuan dari undang-undang ini, maka peran KPPU dan pengadilan sangat menentukan. Kalau tidak perilaku para pelaku bisnis yang curang akan sulit untuk dihindarkan, dan hal ini akan merugikan secara umum kepada kepentingan konsumen. $\sqsupset$

\footnotetext{
${ }^{21}$ Ibid. HIm. 20.
} 


\section{Daftar Pustaka}

Abdul Gafur. 2000. Hari-hari Terakhir. Seorang Presiden. Jakarta: Pustaka Sinar Harapan.

Ahmad Yani dan GunawanWidjaja. 1999. Anti Monopoli. Jakarta: PT Raja Grafindo Persada.

Abdul Hakim G. Nusantara dan Benny K. Harman. 1999. Analisis dan Perbandingan Anti Monopoli. Jakarta: Kelompok Gramedia.

Abdul Mannan. 1995. Teori dan Praktik Ekonomi Islam. Yogyakarta: PT. Dana Bhakti Wakaf.

Agus Triyanta. "Resistensi Sistem Bisnis Islami dan Sistem Bisnis Sekuler terhadap Defiasi Pasar." Jurnal Magister Hukum Vol. 2 No. 4. Oktober 2000.

Bryan A. Ganner. 1999. Black's Law, Dictionary. Edition Seventh. St. Paul. Minn: West Group.
Munir Fuady. Hükum Ant Menyongsong Era Persaing Bandung: PT. Citra Aditya Bakti, Normin S. Pakpahàn." "Penemuan Ho Persaingan; Suatu Layanan Anah. Komparatif. "Jurnal Hukum Bisnis Vol. 4, 1998.

Sunaryati Hartono. "Pembangunan Hukum Ekonomi Indonesia dalam Rangka - Mewujudkan Perilaku 'Bisnis dan Persaingan Usaha yang Sehat." Makalah disampaikan pada Seminar Membenahi Perilaku Bisnis Melalui UndangUndang Nomor 5 Tahun 1999 tentang Larangan Praktik Monopoli dan Persaingan Usaha Tidak Sehat. Diselenggarakan oleh Sidharta Pohan Prastowo Associates. Hotel Grand Aquila. Bandung 19 Juni 1999.

R.B. Suhartono. "Konglomersai dan Rélevansi UU Antitrust/UU Antimonopoli di Indonesia. " Jurnal Hukum Bisnis Vol. 4, 1998. 